\title{
KORELASI ANTARA PENGELOLAAN SISTEM INFORMASI SEKOLAH DENGAN EFEKTIVITAS KERJA PEGAWAI
}

\author{
Hardiansyah $^{1}$, Yulfani Cohan ${ }^{2}$ \\ Administrasi Pendidikan, FIP IKIP Mataram \\ Email: yullfany@yahoo.com
}

\begin{abstract}
The statement of the problem in this research is there any correlation between school management information system and work effectiveness of staff at MA. Ad-Dinul Qayyim, Gunung Sari West Lombok in 2014/2015. The purpose of this research was to determine the correlation between school management information system and work effectiveness of staff at MA. Ad-Dinul Qayyim, Gunung Sari West Lombok in 2014/2015. The method of data gathering used questionnaire and interview. The data were analyzed statically by using correlation product moment. The results indicated that, $\mathrm{r}$-table equals to $0,311, \mathrm{r}$-test at the significance level of $5 \%$ with $\mathrm{N}=48$ It was obtained 0,248 this shows that $r$ - test is bigger than r-table or $0,311>0,248$, thus the result of this research is significant. This means $\mathrm{H}_{0}$ is rejected and $\mathrm{H}_{\mathrm{a}}$ is accepted. Hence, it can be concluded that there is a correlation between school management information systems and work effectiveness of staff at MA. Ad-Dinul Qayyim, Gunung Sari West Lombok in 2014/2015.
\end{abstract}

\section{Keywords: Information system, work effectiveness}

\begin{abstract}
Abstrak: Rumusan masalah dalam penelitian ini adalah Apakah ada korelasi antara pengelolaan sistem informasi sekolah dengan efektivitas kerja pegawai di MA. Ad-Dinul Qayyim, Gunung Sari Lombok Barat tahun 2014/2015. Sedangkan tujuan dari penelitian ini adalah Ingin mengetahui korelasi antara pengelolaan sistem informasi sekolah dengan efektivitas kerja pegawai di MA. Ad-Dinul Qayyim, Gunung Sari, Lombok Barat tahun 2014/2015. Metode pengumpulan data yang digunakan dalam penelitian ini yaitu dengan metode angket sebagai metode pokok dan metode wawancara sebagai metode pelengkap. Sedangkan metode analisis data yang digunakan dalam penelitian ini adalah metode analisis statistik dengan rumus koefisien korelasi product moment. Berdasarkan hasil analisis data dalam dalam penelitian ini, diperoleh nilai $r_{\text {hitung }}$ sebesar 0,311 , selanjutnya nilai tersebut dikonsultasikan dengan nilai $r_{\text {tabel }}$ product momen pada taraf signifikansi $5 \%$ dengan $\mathrm{N}=48$ diperoleh nilai sebesar 0.284 . Kenyataan tersebut menunjukan bahwa $r_{\text {hitung }}$ lebih besar dari $r_{\text {tabel }}$ atau $0,311>0.284$, maka hasil analisis data dalam penelitian ini dinyatakan signifikan. Hal ini berarti $\mathrm{H}_{0}$ ditolak dan $\mathrm{H}_{\mathrm{a}}$ diterima

Kesimpulan yang diperoleh dalam penelitian ini adalah Ada korelasi antara pengelolaan sistem informasi sekolah dengan efektivitas kerja pegawai di MA. Ad-Dinul Qayyum, Gunung Sari Lombok Barat Tahun Pelajaran 2014/2015.
\end{abstract}

\section{Kata Kunci: Sistem Informasi dan Efektivitas Kerja}


Latar Belakang

Pada era kemajuan teknologi informasi sekarang ini, institusi pendidikan berusaha memanfaatkan perkembangan dan kemajuan teknologi informasi dengan mengakses serta menyajikan informasi pendidikan.Sehingga dalam rangka meningkatkan kualitas pendidikan, sebuah lembaga pendidikan hendaknya memiliki Sistem Informasi yang dapat membantu sekolah dalam mengelola kegiatan belajar mengajar dengan efektif dan efisien.

Ketersediaan sarana dan prasarana sangat mendukung cepat atau tidaknya pengelolaan suatu informasi, untuk itu perlu di tuntut untuk kelengkapannya seperti ketersediaan komputer yang cukup, jaringan internet yang cepat. Sedangkan kenyataan yang ada di MA. Ad-Dinul Qayyim adalah masih kurangnya ketersediaan komputer untuk para pegawai dan jaringan internet yang terbatas yakni hanya menggunakan satu modem saja untuk semua pegawai jadi harus menunggu dan bergiliran untuk terkoneksi internet.

Berdasarkan permasalahan diatas, penulis tertarik untuk mengadakan penelitian tentang: Korelasi Antara Pengelolaan Sistem Informasi Sekolah Dengan Efektivitas Kerja Pegawai di MA Ad-Dinul Qayyim, Gunung Sari Lombok Barat Tahun 2014/2015".

\section{Kajian Literatur}

Menurut pustaka [Budihar95] dalam Eddy (2005: 40) sistem informasi adalah "adalah suatu sistem manusia - mesin yang terpadu untuk menyajikan informasi guna mendukung fungsi operasi, manajemen dan pengambilan keputusan dalam organisasi". Setiap sistem informasi memiliki tujuannya masing-masing sesuai dengan tujuan organisasinya. Contohnya sistem informasi rumah sakit bertujuan untuk menyajikan informasi rumah sakit, melakukan pemantauan, pengendalian, dan evaluasi penyeleggaraan rumah sakit. Manfaat adanya sistem informasi menurut Indrajit dalam Ety dkk (2001:21) yaitu: 1) Menyajikan informasi guna mendukung pengambilan suatu keputusan. 2) Menyajikan informasi guna mendukung operasi harian. 3) Menyajikan informasi yang berkenaan dengan kepengurusan. Menurut Setiawan (2007:350), menyatakan bahwa unsur-unsur Sistem informasi adalah sebagai berikut: (1) Perangkat Keras (Hardware), (2) Perangkat Lunak (Software), dan (3) Manusia (Brainware).

Menurut Amsyah (2003:131) efektivitas kerja didefinisikan sebagai berikut: "Efektivitas adalah kegiatan dengan mulai adanya fakta kegiatan sehingga menjadi data,baik yang berasal dari hubungan dan transaksi internal dan eksternal maupun berasal dari hubungan antar unit dan di dalam unit itu sendiri". Stephen P.Robbins (1996:24) menyatakan bahwa faktor-faktor yang mendorong peningkatan efektivitas kerja pegawai,adalah:“(1) Sikap (disiplin), (2) Kepentingan atau minat, (3) Motif, (4) Pengalaman masa lalu, (5) Penerapan (dispektasi), (6) kendali (kontrol pengawasan), (7) motivasi, (8) pengungkapan emosional, (9) Informasi”. Menurut Richard dan M. Steers (1980:192) untuk mengukur efektivitas kerja pegawai yang meliputi unsur kemampuan menyesuaikan diri/ prestasi kerja dan kepuasan kerja. 


\section{Metode Penelitian}

Sumber Informasi dalam penelitian ini adalah seluruh pegawai yang ada di MA. Ad-Dinul Qayyim Gunung Sari tahun pelajaran 2014/2015 yang berjumlah 48 orang. Dan yang menjadi obyek dalam penelitian ini adalah pengelolaan sistem informasi terdiri dari perangkat keras komputer, perangkat lunak komputer dan efektivitas kerja pegawai di MA. Ad-Dinul Qayyim, Gunung Sari Lombok Barat tahun pelajaran 2014/2015. Untuk memperoleh data yang diperlukan dalam penelitian ini penulis mengunakan metode angket sebagai metode pokok dan wawancara sebagai metode pelengkap. Sehubungan dengan penelitian ini, data yang diperoleh adalah data kualitatif karena berupa angka kausal jawaban observasi tentang kemampuan penggunaan sistem informasi dan angka tentang efektivitas kerja pegawai. Dengan demikian analisa data menggunakan analisis statistic.

Data yang diperoleh akan dianalisis dengan menggunakan rumus Koefisien Korelasi "Product Moment", dengan rumus sebagai berikut:

$$
\boldsymbol{r}_{x y}=\frac{\sum x y}{\sqrt{\left(\sum x^{2}\right)\left(\sum y^{2}\right)}}
$$

Keterangan :

$$
\begin{array}{ll}
\boldsymbol{r}_{x y} & =\text { Koefisien korelasi product moment } \\
x y & =\text { Hasil perkalian antara variabel } \mathrm{x} \text { dan variabel } \mathrm{y} \\
x & =\text { Skor angket pengelolaan sistem informasi sekolah } \\
y & =\text { Skor angket efektivitas kerja pegawai } \\
\sum & =\text { Sigma (jumlah) (Hadi, } 2001: 206) .
\end{array}
$$

Untuk mengetahui seberapa kuat hubungan antara variabel, dapat digunakan pedoman seperti yang tertera pada table 3.1 berikut.

\begin{tabular}{|c|c|}
\hline Interval Koefisien & Tingkat Hubungan \\
\hline $0,00-0,199$ & Sangat rendah \\
$0,20-0,399$ & Rendah \\
$0,40-0,599$ & Sedang \\
$0,60-0,799$ & Kuat \\
$0,80-1,000$ & Sangat kuat \\
\hline
\end{tabular}

(Sugiono, 2013: 257).

\section{Hasil Penelitian}

Adapun hasil penelitiannya, diawali dengan mendapatkan dokumen nama-nama pegawai yang diberikan angket di MA.Ad-Dinul Qayyim dapat disajikan pada tabel berikut:

Data yang dibutuhkan dalam penelitian ini adalah data tentang korelasi antara pengelolaan sistem informasi sekolah dengan efektivitas kerja pegawai di MA. AdDinul Qayyim, Gunung Sari Lombok Barat tahun pelajaran 2014/2015 yang didapatkan melalui metode angket yang dilaksanakan dengan dua tahap yaitu: a) 
menyebarkan angket kepada para pegawai, b) penarikan angket, dan c) pemberian skor angket.

\section{Pembahasan}

1. Memasukkan Data Kedalam Rumus

$$
\begin{array}{ll}
\text { Rata-rata } \mathrm{x}=51,5 & \text { Rata-rata } \bar{y}=49,8 \\
\sum x^{2}=2337,92 & \sum y^{2}=513,31 \\
\sum x y=340,88 & \\
\boldsymbol{r}_{\boldsymbol{x} y}=\frac{\sum x \boldsymbol{y}}{\sqrt{\left(\sum \boldsymbol{x}^{2}\right)\left(\sum \boldsymbol{y}^{\mathbf{2}}\right)}} & \\
\boldsymbol{r}_{\boldsymbol{x} y}=\frac{340,88}{\sqrt{(2337,92)(513,31)}} & \\
\boldsymbol{r}_{\boldsymbol{x} y}=\frac{340,88}{\sqrt{1200077,72}} & \\
\boldsymbol{r}_{\boldsymbol{x}}=\frac{340,88}{1095,48} & \\
\boldsymbol{r}_{\boldsymbol{x}}=0,311 &
\end{array}
$$

2. Menguji nilai $\boldsymbol{r}_{\boldsymbol{x} y}$

Nilai $r_{x y}$ diperoleh sebagai hasil analisis data dalam penelitian ini adalah sebesar 0,311, Selanjutnya hasi analisis data tersebut dikonsultasikan dengan nilai $r$ Product Moment dengan $\mathrm{N}=48$ pada taraf signifikan 5\%. Berdasarkan taraf signifikansi $5 \%$ dengan $\mathrm{N}=48$, ternyata batas angka perolehan hipotesis nihil adalah 0,284. Ini berarti $r_{\text {hitung }}=0,311$ lebih besar dari $r_{\text {tabel }}=0,284$ $\left(r_{\text {hitung }}=0,311>r_{\text {tabel }}=0,284\right)$ yang berarti hasil penelitian ini adalah signifikan. Dengan demikian berarti pula Hipotesis Nol $\left(\mathrm{H}_{0}\right)$ ditolak, sedangkan hipotesis alternatif $\left(\mathrm{H}_{\mathrm{a}}\right)$ diterima.

3. Menarik Kesimpulan

Karena nilai penelitian ini berada diatas angka batas penolakan $\left(\mathrm{H}_{0}\right)$, maka hipotesisi nol $\left(\mathrm{H}_{0}\right)$ yang berbunyi : Tidak ada korelasi antara pengelolaan sistem informasi sekolah dengan efektivitas kerja pegawai di MA. Ad-Dinul Qayyum, Gunung Sari Lombok Barat Tahun Pelajaran 2014/2015, ditolak, sedangkan hipotesis alternatif $\left(\mathrm{H}_{\mathrm{a}}\right)$ berbunyi : Ada korelasi antara pengelolaan sistem informasi sekolah dengan efektivitas kerja pegawai di MA.Ad-Dinul Qayyum, Gunung Sari Lombok Barat Tahun Pelajaran 2014/2015, diterima.

Berdasarkan hasil analisis data di atas diperoleh nilai sebesar 0,311, sedangkan batas angka penolakan hipotesis nihil yang ditunjukkan dalam $r_{\text {tabel }}$ pada taraf signifikansi 5\% dengan $\mathrm{N}=48$ adalah sebesar 0,284. Hal ini berarti bahwa nilai $r_{\text {hitung }}$ lebih besar dari nilai $r_{\text {tabel }}\left(r_{\text {hitung }}>r_{\text {tabel }}\right)$ yang berarti signifikan. Dengan demikian $\left(\mathrm{H}_{0}\right)$ yang berbunyi: Tidak ada korelasi antara pengelolaan sistem informasi sekolah dengan efektivitas kerja pegawai di MA. Ad-Dinul Qayyum, Gunung Sari Lombok Barat Tahun Pelajaran 2014/2015, ditolak dan $\left(\mathrm{H}_{\mathrm{a}}\right)$ yang berbunyi: Ada korelasi antara pengelolaan sistem informasi sekolah dengan efektivitas kerja 
pegawai di MA. Ad-Dinul Qayyum, Gunung Sari Lombok Barat Tahun Pelajaran 2014/2015, diterima.

Dari hasil penelitian ini membuktikan bahwa pengelolaan sistem informasi sekolah berpengaruh positif terhadap efektivitas kerja pegawai. Untuk mencapai hal tersebut pegawai di tuntut untuk mampu mengelola informasi yang di dapat dan tidak hanya bergantung dari kepala sekolah sebagai pimpinan di sekolah. Serta di tuntut untuk lebih aktif dan kreatif dalam memanfaatkan fasilitas yang ada di sekolah, dan kepala sekolah sebagai pimpinan juga harus menyediakan fasilitas yang dibutuhkan oleh pegawainya untuk menunjang pekerjaanya.

\section{Simpulan}

Simpulan, Berdasarkan hasil analisis data diketahui bahwa nilai $r_{\text {hitung }}$ yang diperoleh dalam penelitian ini sebesar 0,311 lebih besar dari $r_{\text {tabel }}$ Product Moment dengan $\mathrm{N}=$ 48 pada taraf signifikansi $5 \%$ yaitu sebesar $0,284(0,311>0,284)$ yang berarti hasil penelitian ini adalah signifikan.

Dengan demikian dapat disimpulkan bahwa: Ada korelasi antara pengelolaan sistem informasi sekolah dengan efektivitas kerja pegawai di MA. Ad-Dinul Qayyum, Gunung Sari Lombok Barat Tahun Pelajaran 2014/2015 yang tergolong dalam kategori Rendah.

\section{Referensi}

Amsyah, Zulkifli. 2003. Manajemen Sistem Informasi. Jakarta: PT Gramedia Pustaka Utama.

Hadi, Sutrisno. 2001. Statistik II. Yogyakarta: Andi Yogyakarta.

P. Robins, Stephen, 1990, Teori Organisasi, Struktur, Desain dan Aplikasi. Jakarta: Arcan,

Supriani, Yeni. 2010. Hubungan Antara Kemampuan Komunikasi Kepala Sekolah Dengan Kinrja Pegawai Di SMPN Sekecamatan Batukliang Utara: Mataram. FIP IKIP Mataram. 
